\title{
ECOLOGICAL FOOTPRINT ANALYSIS OF CANNED SWEET CORN
}

\author{
Phairat Usubharatana' ${ }^{1}$, Harnpon Phungrassami ${ }^{1}$ \\ 1 Chemical Engineering Department, Faculty of Engineering, Thammasat University, 12121 Pathumthani, \\ Thailand, e-mail: pharnpon@engr.tu.ac.th
}

Received: 2016.03.11

Accepted: 2016.06.01 Published: 2016.07.01

\begin{abstract}
There has been a notable increase in both consumer knowledge and awareness regarding the ecological benefits of green products and services. Manufacturers now pay more attention to green, environmentally friendly production processes. Two significant tools that can facilitate such a goal are life cycle assessment (LCA) and ecological footprint (EF). This study aimed to analyse and determine the damage to the environment, focusing on the canned fruit and vegetable processing. Canned sweet corn (340 g) was selected for the case study. All inputs and outputs associated with the product system boundary were collected through field surveys. The acquired inventory was then analysed and evaluated using both LCA and EF methodology. The results were converted into an area of biologically productive land and presented as global hectares (gha). The ecological footprint of one can of sweet corn was calculated as $6.51 \mathrm{E}-04$ gha. The three factors with the highest impact on ecological footprint value were the corn kernels used in the process, the packaging and steam, equivalent to $2.93 \mathrm{E}-04$ gha, 1.19E-04 gha and 1.17E-04 gha respectively. To promote the sustainable development, the company should develop new technology or utilize better management techniques to reduce the ecological footprint of canned food production.
\end{abstract}

Keywords: ecological footprint, life cycle assessment, sweet corn, food industry

\section{INTRODUCTION}

Global corn production increased from 597 kton in 2004 to 685 kton in 2013 [FAOSTAT 2015]. In Thailand production increased to 2.3 times the 2004 value, i.e. to 11,500 ton in 2013 [FAOSTAT 2015]. This production has resulted in increased environmental pollution. Greenhouse gas (GHG) emissions from the Asian agricultural sector increased by $1.55 \%$ from 1990 to 2012 [FAOSTAT 2015]. The emission of GHG's in Thailand was 58,966 kton in 2004, rising to 70,272 kton in 2012 [FAOSTAT 2015]. N-fertiliser used in agriculture is an important factor responsible for $\mathrm{GHG}$ emissions because some components of $\mathrm{N}$-fertiliser contribute to nitrous oxide $\left(\mathrm{N}_{2} \mathrm{O}\right)$ emissions. Therefore, to control the impact on the environment, a reliable measurement must be set as a benchmark. One popular yardstick used is life cycle assessment (LCA). This is a holistic tool used to assess and quantify environmental impacts, considering all the stages of a product's life from raw material acquisition, manufacture, distribution, use and disposal. LCA has been developed for carbon footprint (CF) methodology. A carbon footprint is the summation of GHG emissions of a product or service throughout its lifetime, expressed as carbon dioxide equivalents $\left(\mathrm{CO}_{2}\right.$ eq). In terms of greenhouse gases the $\mathrm{CF}$ includes emissions of $\mathrm{CO}_{2}, \mathrm{CH}_{4}$ and $\mathrm{N}_{2} \mathrm{O}$ [Roos et al. 2010]. The carbon footprint is an effective environmental impact assessment tool, however, it has certain limitations such as the lack of other impacts involved. As a result, a reduction in carbon footprint level may contribute to the increase of other environmental impacts. The ecological footprint considers and evaluates various other kinds of environmental impacts and integrates them with carbon footprint. Some research has been conducted on the ecological footprint of agriculture such as Italian wine [Niccolucci et al. 2008], tomatoes [Wada 1993], beans, tomatoes, 
cabbages, pineapples and coffee [Cuadra and Bjorklund 2007]. However, no research has been carried out on the ecological footprint of corns.

Therefore, this study focused on the ecological footprint assessment, using both LCA and EF methodology for canned sweet corn with the following objectives: (1) to study the ecological footprint of sweet corn cultivation, (2) to study the ecological footprint of canned sweet corn manufacture and (3) to identify the hot spot of canned sweet corn manufacture throughout the system boundary of the product life cycle.

\section{MATERIALS AND METHODS}

The objective of this research was to study the synergy and application of life cycle assessment (LCA) and ecological footprint (EF) using canned sweet corn production. Previous research conducted on LCA determined that it was difficult to translate the results into a simple and comprehensive interpretation [Camillis et al. 2010, Zamagni et al 2008, Castellani and Sala 2012]. This triggered an effort to simplify the acquired LCA results into a more understandable pattern. Ecological footprints is were applied here to present the LCA results in terms of area, and therefore reflect other aspects of environmental impacts. The conceptual idea of using a hybrid LCA-EF methodology for this study is shown in Figure 1. The research procedures were in the following order: (1) identify the components in each sub-process, namely cultivation and canning and consider them in details, (2) classify the components into impact categories such as global warming and acidification and (3) translate the impact categories into area and global area respectively. LCA methodology was applied during the first and second steps,

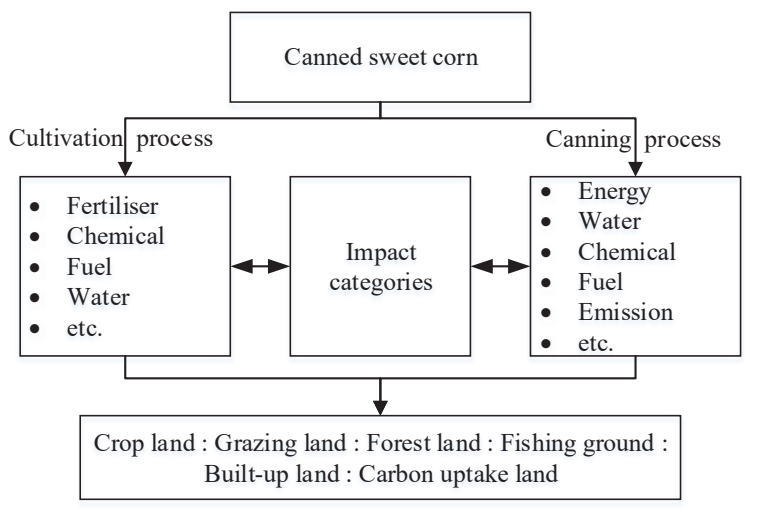

Figure 1. Conceptual idea of the hybrid LCA-EF while EF was used for the assessment of the third procedure.

\section{Life cycle assessment}

LCA is an effective tool to evaluate the environmental impacts of products, services or processes. The results were analysed in quantitative units, based on data gathered from both inputs and outputs of the studied system. Following ISO14040, LCA methodology encompasses four components 1) goal and scope, 2) inventory, 3) impact assessment and 4) interpretation [ISO 14040 2006].

\section{Goal and scope}

In the first step of LCA, the objective was defined, the system boundary was determined and the functional unit was set. LCA was utilised to efficiently evaluate the environmental impacts caused by canned sweet corn production. The results were then used as input for the ecological footprint assessment. The system boundary of the study was classified in two processes; the cultivation process and the production process. The functional unit (fu) was set at one can of sweet corn $(340 \mathrm{~g})$. The functional unit expresses the selected system in quantitative units related to the reference flow [ISO 14040 2006].

\section{Inventory}

The inventory was defined by collecting the primary data through both interview techniques and a questionnaire survey from a canned sweet corn the production company located in central Thailand. However, some data gaps were fulfilled by secondary data such as the production of fertilisers and the chemicals used during both cultivation and manufacture, including electricity production. These data were collected during 2014. During cultivation, the average yield was $1,250,000 \mathrm{~kg} \mathrm{~km}^{-2}\left(12,500 \mathrm{~kg} \mathrm{ha}^{-1}\right)$ and 15-15-15 and 46-0-0 fertilisers were used at application rates of $31,250 \mathrm{~kg} \mathrm{~km}^{-2}\left(312.5 \mathrm{~kg} \mathrm{ha}^{-1}\right)$ and 18,750 $\mathrm{kg} \mathrm{km}^{-2}\left(187.5 \mathrm{~kg} \mathrm{ha}^{-1}\right)$ respectively. The distance from the cultivation areas to the manufacturing plant averaged $238 \mathrm{~km}$. The production process was divided into five units as follow:

1) Acquisition and preparation of raw material: the corns were placed on the conveyor line for size sorting and then fed into a corn cutter equipped with a roller conveyor and a 
set of cutter knives. The chopped corns were then processed through a husking machine by husker rolls and steamed to make them easier to shuck. The corn kernels were extracted from the corncobs using a corn sheller. The whole corncobs were then inserted into spiral tubes, with a cutting part to shell only the required kernels.

2) Kernel sorting: the corn kernels were then carried on a conveyor belt through a vibrating grader to sort them by size and remove foreign articles such as husk waste. They were then washed to clean off any waste and foreign articles.

3) Filling: the corn kernels were filled into cans, followed by salted water or syrup. The kernelfilled cans were then conveyed to an exhausting machine where the air inside was drawn out and the cans were sealed with caps.

4) Heat sterilisation: microorganisms in the product were exterminated by heat in a high-pressure steam blancher.

5) Storage: after cooling, canned sweet corn was stored on shelves at particular storage locations.

The system boundary of this study ended at the factory gate. This can be regarded as a cradleto-gate life cycle inventory, where the distribution of the product was not taken into account. On the other hand, inputs namely electricity, water, steam, sugar and salt as well as packaging in aluminum cans and cardboard cartons were considered in this study.

\section{Impact assessment}

In the final stage, the environmental impacts were assessed using inputs and outputs from the life cycle inventory and classified into individual impact potential for further analysis of their ecological footprint. The focused potentials were global warming, water footprint and acidification. Global warming potential (GWP) was evaluated using IPCC2007. Acidification and water footprints were analysed through $\mathrm{ReCiPe}$ methodology. The water footprint assessment methodology presented by Mekonnen and Hoekstra [2011] was applied to quantify the amount of water used during cultivation.

\section{Ecological footprint}

The term ecological footprint (EF) was first introduced by Rees [1992] and Wackernagel and
Rees [1996]. It is a measure of the human impact on Earth's ecosystems and comprise six land use types namely cropland, grazing land, forest land, fishing ground, built-up land and carbon uptake land [Global Footprint Network 2009]. To calculate the total EF selected impact categories are first converted to the corresponding area which can be either land or water. The equivalence factor is then applied to convert the calibrated area into global hectares (gha) as shown in Equation 1:

$$
E F_{T}=\sum_{i=1}^{6} E F_{i} \times E Q F_{i}
$$

where: $E F_{T}$ - the total $E F$ in gha; $i$ - the six land use types; $E F_{i}-E F$ of each land use type and $E Q F_{i}$ - the equivalence factor of each land use type.

The equivalence factor translates a specific area type into a universal unit of productive area, also called a global hectare. The equivalence factors used in this research are shown in Table 1.

The calculation to convert each component into a particular area type is based on conversion factors. If the conversion factors are not available the components converted to $\mathrm{CO}_{2}$ first, using IPCC2007 methodology for the LCA. The acquired $\mathrm{CO}_{2}$ value is then converted to the area of forest needed for sequestration (carbon uptake land) [Niccolucci et al. 2008, Cerutti et al. 2011]. This study involved only agricultural production, and therefore, the grazing land and fishing ground categories were not relevant [Niccolucci et al. 2008]. However, the transportation of the raw materials during the cultivation and production processes was included. This was analysed based on the combustion rate in terms of the $\mathrm{CO}_{2}$ which would subsequently be shifted to carbon uptake land.

\section{Crop land}

The EF of crop land is basically land used for the production of food, feed for livestock and oil crops. The EF of grazing land measures the

Table 1. Equivalence factors [Global Footprint Network 2010]

\begin{tabular}{|l|c|}
\hline \multicolumn{1}{|c|}{ Productive land type } & Equivalence factor $\left(\right.$ gha ha-1 $\left.^{-1}\right)$ \\
\hline Cropland & 2.51 \\
\hline Grazing land & 0.46 \\
\hline Forest & 1.26 \\
\hline Fishing land & 0.37 \\
\hline Built-up land & 2.51 \\
\hline
\end{tabular}


area of grassland necessary to support livestock [Ewing et al. 2008]. Crop land and grazing land have similar land usage and so an increase in crop feed may cause a reduction in demand on grazing capacity [Kitzes 2008]. However, only crop land was focused on this study, because grazing land was irrelevant. The EF of crop land was determined using Equation 2:

$$
E F_{\text {crop land }}=\sum_{i=1}^{n} \frac{A_{i}}{Y_{i}}
$$

where: $E F_{\text {crop land }}$ - the total $E F$ of the crop land in gha; $i$ - crop type related to the finished product; $A_{i}$ - amount of crop i per functional unit in $\mathrm{kg} \mathrm{i} \mathrm{fu}^{-1}$ and $Y_{i}$ - world average productivity in $\mathrm{kg} \mathrm{ha}^{-1}$

\section{Forest land}

The conventional EF of forest land represents the area of world average forest land required to supply wood for construction, fuel and paper [Kitzes 2008]. It can be represented by Equation 3:

$$
E F_{\text {forest land }}=\sum_{i=1}^{n} \frac{F_{i}}{Y_{i}}
$$

where: $E F_{\text {crop land }}$ - the total $\mathrm{EF}$ of forest land in gha; $i$ - forest type related to the finished product; $F_{i}$ - the amount of material i per functional unit in $\mathrm{kg} \mathrm{i} \mathrm{fu}^{-1}$ and $Y_{i}$ - world average productivity in $\mathrm{kg} \mathrm{ha}^{-1}$.

\section{Built-up land}

Built-up land represents the area of land covered by human infrastructures such as transportation, housing, industrial structures and reservoirs. However, built-up land embodied in traded goods was not included in the calculation due to lack of data. Moreover, when considered per functional unit, the impact of built-up land was minimal. Therefore, it was not considered in this study.

\section{Emission uptake land}

The conventional EF of carbon uptake land was calculated from the area of land for $\mathrm{CO}_{2}$ sequestration. The results showed that a quarter of $\mathrm{CO}_{2}$ emissions were sequestered by the oceans. After deducting the $\mathrm{CO}_{2}$ sequestered by the oceans, the remianing EF of carbon uptake land was calculated [IGBP 2013]. Hence, the equation for carbon uptake is represented by Equation 4 [Lee and Peng 2014]:

$$
E F_{\text {carbon uptake land }}=\sum \mathrm{CO}_{2} \times\left(\frac{1-0.25}{C F_{c}}\right)
$$

where: $E F_{\text {carbon uptake land }}-$ the total $\mathrm{EF}$ of forest land due to carbon sequestration in gha; $\mathrm{\Sigma CO}_{2}$ - the total $\mathrm{CO}_{2}$ emissions in the product system per functional unit, $\mathrm{kgCO}_{2} \mathrm{fu}^{-1}$ and $\mathrm{CF}_{c}$ - the conversion factor of $\mathrm{CO}_{2}-3704$ $\mathrm{kg} \mathrm{CO}_{2}$ ha $^{-1}$ [Global Footprint Network 2009, Scotti et al. 2012, Kissinger and Gottlieb 2012].

\section{Sulphur uptake land}

Acidification is defined as a regional impact and it was calculated using a factor which converted a ton of sulphur dioxide $\left(\mathrm{SO}_{2}\right)$ to the area needed for its sequestration at $1.55 \mathrm{~km}^{2}(155$ ha) [Diaz et al. 2012]. Therefore, the equation used to calculate sulphur uptake land is shown as Equation 5:

$$
E F_{\text {sulphur uptake land }}=\frac{\sum S_{e}}{C F_{s}}
$$

where: $\mathrm{EF}_{\text {sulphur land }}$ - the total $\mathrm{EF}$ of forest land due to sulphur sequestration in gha; $\Sigma S_{e}-$ the total $\mathrm{SO}_{2}$ emissions in the product system per functional unit in $\mathrm{kgSO}_{2} \cdot \mathrm{fu}^{-1}$ and $\mathrm{CF}_{s}-$ the conversion factor of $\mathrm{SO}_{2}$ in $\mathrm{kgSO}_{2} \cdot \mathrm{ha}^{-1}$.

\section{Water consumption}

To evaluate the ecological footprint of water consumption the evapotranspiration rate of the crops is required. Forests are water producers and whereby the consumption of this resource is included in that of the forest land [Solis-Guzman 2013]. The forest productivity $\left(\mathrm{m}^{3} \mathrm{~km}^{-2} \mathrm{y}^{-1}\right)$ was evaluated using the concept of Yoshikawa [Yoshikawa et al. 2011]. In Thailand, water resources are derived from the average rainfall equivalent to $1572.5 \mathrm{~mm}$ or $15,725 \mathrm{~m}^{3} \mathrm{ha}^{-1}\left(1572.5 \mathrm{E}+03 \mathrm{~m}^{3}\right.$ $\mathrm{km}^{-2}$ ). Hence, the ecological footprint of such water use can be obtained from Equation 6:

$$
E F_{\text {water consumption land }}=\frac{\sum W}{C F_{w}}
$$

where: $E F_{\text {water consumption land }}$ - the total $\mathrm{EF}$ of forest land due to water consumption in gha; $\sum W$ - the total water consumption in the product system per functional unit in $\mathrm{m}^{3} \cdot \mathrm{fu}^{-1}$ and $C F_{\mathrm{w}}$ - the conversion factor of water consumption in $\mathrm{m}^{3} \cdot \mathrm{ha}^{-1}$.

\section{Water footprint}

For the water used during cultivation, the water footprint level can be obtained by the evapotranspiration (ET) rate of the respective crops. 
This can be gained from two sources - the crop coefficient $\left(\mathrm{K}_{\mathrm{c}}\right)$ and the reference crop evapotranspiration $\left(\mathrm{ET}_{0}\right)$, expressed from the analysis based on the local climate in that specific area through the Penman Monteith method [Irrigation Water Management 2011]. Consequently, crop water use (CWU) is given by Equation 7:

$$
E T=K_{c} \times E T_{0}
$$

The total CWU throughout the crop life cycle is the sum of the evapotranspiration rate $\left(\mathrm{mm} \mathrm{day}{ }^{-1}\right)$ and $\mathrm{Y}$ is the crop yield $\left(\mathrm{kg} \mathrm{ha}^{-1}\right)$ as presented by Equation 8 and Equation 9:

$$
\begin{gathered}
C W U=10 \times \sum_{d=1}^{l g p} E T \\
W F=\frac{C W U}{Y}
\end{gathered}
$$

\section{RESULTS AND DISCUSSION}

\section{Life cycle impact assessment}

\section{Cultivation}

From the information collected through the questionnaires from the factory, the fertilizers used were only two formulas -15-15-15 and 46$0-0$. These were applied at up to $40 \mathrm{~kg}$ per 1 ton of sweet corn production. However, to produce one can of sweet corn required $7.38 \mathrm{~kg}$ of corn kernels. In addition, diesel consumption during cultivation activities accounted for two litres per ton of sweet corn, while the chemical paraquat and alachlor, commonly applied for weed control, were used at a rate of $0.16 \mathrm{~kg}$ and $0.07 \mathrm{~kg}$ per ton of sweet corn production respectively. This information and life cycle impact assessment results indicated that fertilisers were the major contributors to greenhouse gases and resulted in the fertiliser manufacturing process to be considered as an indirect emission. The $\mathrm{N}_{2} \mathrm{O}$ released as a result of fertiliser use was regarded as a direct emission (Table 2). The impact from sulphur dioxide emission was also mostly a result of fertiliser production, representing over $93.5 \%$ of the total amount. $\mathrm{N}$-fertiliser production from $15-15-15$ and 46-0-0 fertiliser was the prominent cause of sulphur dioxide release. Water consumption was classified into direct and indirect. Direct water, referred to water consumption during cultivation, also known as crop water use, while indirect water was the amount of water used during material production. The results showed that direct water for corn production was $0.208 \mathrm{~m}^{3}$ per can of sweet corn and the indirect water for fertiliser production accounted for $96.7 \%$ of the total indirect water.

\section{Processing}

The analysis of results from the life cycle impact assessment of sweet corn processing is presented in Table 3. The GHG emissions during the production stage came chiefly from can and cardboard production as packaging (37\%). The secondary cause was the water treatment (25\%) owing to the methane emission from open-pond treatment without aeration. The depth of the pond was over two metres. The tertiary contribution was from steam production $(21 \%)$. The reason for this was the fuels required for the process as both biomass and coal. Sulphur dioxide emission was caused by can and steam production at 48 and $47 \%$ respectively. Can production was the main factor for water-related impact at $58 \%$ while ingredient production contributed $23 \%$.

When considering the impacts caused by both processes, GHG emissions were caused mainly by the production and application of fertilisers $(59 \%)$, followed by subsidiary contributions from packaging production (25\%). Sulphur dioxide emission was also caused by can production, steam production and fertiliser production at 36 , 35 and $23 \%$ respectively. Ragarding the impact from water use, the water consumption for culti-

\begin{tabular}{|c|c|c|c|c|c|}
\hline \multirow{2}{*}{ Process } & \multicolumn{2}{|c|}{ GHGs $\left(\mathrm{kgCO}_{2} \mathrm{eq} \mathrm{fu}{ }^{-1}\right)$} & \multirow[t]{2}{*}{$\mathrm{SO}_{2}\left(\mathrm{gSO}_{2} \mathrm{eq} \mathrm{fu}{ }^{-1}\right)$} & \multicolumn{2}{|c|}{ Water $\left(\mathrm{m}^{3} \mathrm{fu}^{-1}\right)$} \\
\hline & Direct & Indirect & & Direct & Indirect \\
\hline Total & 0.052 & 0.060 & 0.418 & 0.208 & 0.001 \\
\hline Fertiliser & 0.052 & 0.059 & 0.391 & & 0.001 \\
\hline Chemical & & $<2.0 \mathrm{E}-5$ & $<2.0 \mathrm{E}-5$ & & $<2.0 \mathrm{E}-5$ \\
\hline Diesel & $<1.0 \mathrm{E}-4$ & $<5.0 \mathrm{E}-4$ & 0.008 & & $<1.0 \mathrm{E}-5$ \\
\hline Corn & & & & 0.208 & \\
\hline
\end{tabular}
vation activities was the highest at $87 \%$.

Table 2. Life cycle impact assessment of the cultivation process 
Table 3. Life cycle impact assessment of canned sweet corn processing

\begin{tabular}{|l|c|c|c|}
\hline \multicolumn{1}{|c|}{ Process } & $\mathrm{GHGs}\left(\mathrm{kgCO}_{2} \mathrm{eq} \mathrm{fu}^{-1}\right)$ & $\mathrm{SO}_{2}\left(\mathrm{gSO}_{2} \mathrm{eq} \mathrm{fu}^{-1}\right)$ & Water $\left(\mathrm{m}^{3} \mathrm{fu}^{-1}\right)$ \\
\hline Total & 0.220 & 1.257 & 0.031 \\
\hline Ingredient (sugar, salt) & 0.005 & 0.017 & 0.007 \\
\hline Water & 0.001 & 0.001 & 0.002 \\
\hline Packaging & 0.082 & 0.607 & 0.018 \\
\hline Electricity & 0.028 & 0.033 & $<1.3 \mathrm{E}-04$ \\
\hline LPG & 0.001 & 0.001 & $<1.0 \mathrm{E}-06$ \\
\hline Diesel & 0.002 & 0.002 & $<2.0 \mathrm{E}-06$ \\
\hline Steam & 0.047 & 0.588 & 0.003 \\
\hline Wastewater treatment & 0.054 & 0.001 & $<4.3 \mathrm{E}-06$ \\
\hline Transportation & $<2.0 \mathrm{E}-05$ & 0.006 & $<1.0 \mathrm{E}-07$ \\
\hline
\end{tabular}

\section{Ecological footprint}

When applied to the agricultural sector, the three land types considered to describe the land composition of farms are crop land, forest land and $\mathrm{CO}_{2}$ uptake land [Cerutti et al. 2011]. To evaluate the ecological footprint of the cultivation process, the yield has to be involved as presented in Equation 9. However, since the world average yield of sweet corn was not available in FAOSTAT, the value for the United States was applied in this study was $77.45 \mathrm{~kg} \mathrm{~km}^{-2}$ (or 7,745 $\mathrm{kg} \mathrm{ha}^{-1}$ ) [National Corn Growers Association 2013]. In terms of the yield of eucalyptus used to produce the paper element in the packaging, information was gained from the yield of eucalyptus in Thailand at 0.75 ton $\mathrm{km}^{-2}$ (75 ton ha- $\left.{ }^{-1}\right)$ [Thaiusa 2002]. The average yield of sugar at 0.0067 ton $\mathrm{km}^{-2}\left(0.67\right.$ ton ha- $\left.{ }^{-1}\right)$ was obtained from
FAOSTAT [FAOSTAT 2015]. The forest land exploited for the plantation of palm shells used in steam production was determined to be 0.168 ton $\mathrm{km}^{-2}$ (16.8 ton ha-1) [Dallinger 2011]. This was based on the average yield of fresh fruit branch (FFB) at 16.8 ton $\mathrm{ha}^{-1}$. If the weight of FFB is assumed at $100 \%$, then the allocation percentage by mass of the palm kernel is 7\% [Ohimain et al. 2013. Therefore, the area required to produce the palm kernel should be allocated by the mass allocation method. The forest area can absorb both $\mathrm{CO}_{2}$ and $\mathrm{SO}_{2}$, therefore, the gas that required the highest area for sequestration was selected for the EF calculation to avoid double counting. As a result, the acquired ecological footprints are shown in Table 4. The total ecological footprint of one can of sweet corn was expressed at 6.51E-04 gha, with $3.71 \mathrm{E}-04$ gha caused by the cultivation process and $2.80 \mathrm{E}-04$ gha by processing. The three

Table 4. Ecological footprint of one can of sweet corn

\begin{tabular}{|l|c|c|c|c|}
\hline \multicolumn{1}{|c|}{ Process } & Crop land (gha) & Forest land (gha) & $\mathrm{CO}_{2}$ uptake land (gha) & Total (gha) \\
\hline Cultivation & & & & $7.63 \mathrm{E}-05$ \\
\hline Fertiliser & & & $7.63 \mathrm{E}-05$ & $6.08 \mathrm{E}-09$ \\
\hline Chemical & & & $6.08 \mathrm{E}-09$ & $1.48 \mathrm{E}-06$ \\
\hline Diesel & $2.77 \mathrm{E}-04$ & & $1.48 \mathrm{E}-06$ & $2.93 \mathrm{E}-04$ \\
\hline Corn & & & $1.67 \mathrm{E}-05$ & \\
\hline Processing & $1.78 \mathrm{E}-05$ & & $3.28 \mathrm{E}-06$ & $2.11 \mathrm{E}-05$ \\
\hline Ingredient (sugar, salt) & & & $2.61 \mathrm{E}-07$ & $2.61 \mathrm{E}-07$ \\
\hline Water & & $1.72 \mathrm{E}-07$ & $1.19 \mathrm{E}-04$ & $7.19 \mathrm{E}-04$ \\
\hline Packaging & & & $7.20 \mathrm{E}-06$ & $2.73 \mathrm{E}-07$ \\
\hline Electricity & & & $2.73 \mathrm{E}-07$ & $4.68 \mathrm{E}-07$ \\
\hline LPG & & & $4.68 \mathrm{E}-07$ & $1.17 \mathrm{E}-04$ \\
\hline Diesel & & & $1.15 \mathrm{E}-04$ & $1.38 \mathrm{E}-05$ \\
\hline Steam & $1.94 \mathrm{E}-06$ & & $1.38 \mathrm{E}-05$ & $1.17 \mathrm{E}-06$ \\
\hline Wastewater treatment & & & $1.17 \mathrm{E}-06$ & $6.51 \mathrm{E}-04$ \\
\hline Transportation & & & & \\
\hline Total & & & & \\
\hline
\end{tabular}


highest contributors were sweet corn kernel production, packaging and steam at 2.93E-04 gha, $1.19 \mathrm{E}-04$ gha and 1.17E-04 gha respectively.

The analysis of the results based on the life cycle assessment and ecological footprint of the canned sweet corn product is a key decision making toola for manufacturing plants to streamline their products to become more environmentally friendly. These efficiency tools can be synergised to support each other to visualise improved environmental impacts. The hybrid LCA-EF method can help to establish sustainable development for eco-friendly factory products. Results indicated that the hot spots of canned sweet corn production were (1) corn kernels, therefore further studies of corn genetics are necessary to develop hybrids requiring less water to produce higher yields; (2) can production - thus can manufacturers must find ways to mitigate pollution release to the environment and canned sweet corn manufacturers need to look for alternative packaging instead of using conventional aluminum cans; (3) chemical fertilisers, -which cause the most pollution and should be replaced by organic fertilisers and (4) the introduction of biomass for steam production.

\section{Possibility of environmental impact improvement}

This study conducted an analysis to identify the effects of possible changes to the life cycle assessment and ecological footprint. Data in Tables 2, 3 and 4 were presented as the base case and four options were considered; (1) the effect of decreasing raw material used as aluminum cans by $10 \%,(2)$ the effect of changing the chemical fertiliser to organic fertiliser by $10 \%$, (3) the effect of changing coal to biomass for steam production by $10 \%$ and (4) the effect of decreasing the cardboard material used by $10 \%$. The results are shown in Table 5. Comparing to the base case, option 1 produced the highest negative environmental impact change. Decreasing aluminum cans by $10 \%$ resulted in a $2.4 \%$ decrease in life cycle im- pact assessment (LCIA) in terms of $\mathrm{CO}_{2}$ eq and $1.7 \%$ in the EF result. For option 2, changing to organic fertilisers by $10 \%$ resulted in a $1.8 \%$ decrease in LCIA in terms of $\mathrm{CO}_{2}$ eq. For option 3, the energy content of both coal and palm kernel as a biomass must be known. The energy contents of coal and the biomass were estimated at 10.47 $\mathrm{MJ} \mathrm{kg}{ }^{-1}$ and $18.53 \mathrm{MJ} \mathrm{kg}^{-1}$ respectively (DEDE 2014). The result of LCIA for the third option was similar to the base case in terms of $\mathrm{CO}_{2}$ eq. For option 4, only the sulphur dioxide equivalent impact decreased due to reducing the $\mathrm{SO}_{2}$ eq of cardboard production. Overall, environmental impact improvements can be used as starting points or guidelines to select options to achieve the goal of sustainable development.

\section{CONCLUSIONS}

To assess the environmental impacts complying with LCA methodology, both inputs and outputs associated with the selected product were comprehensively taken into consideration within the explicit system boundary. The acquired results were used to determine the ecological footprints. The results from this study indicated that when $\mathrm{CO}_{2}$ eq was considered, the impacts were caused mainly during the production process rather than during cultivation. In contrast, when the ecological footprint was analysed, cultivation was mainly responsible for the impacts at $3.71 \mathrm{E}-04$ gha more than production at $2.80 \mathrm{E}-04$ gha. These results add wider dimensions to the perception of environmental impacts. Moreover, one possible method to increase sustainable development is reducing the raw materials used in produce the packaging production.

\section{REFERENCES}

1. Castellani V., Sala S. 2012. Ecological footprint and life cycle assessment in the sustainability assessment of tourism activities, Ecol Indic, 16, 135-147.

Table 5. Life cycle impact assessment of the four options

\begin{tabular}{|l|c|c|c|c|}
\hline \multicolumn{1}{|c|}{ Opition } & $\mathrm{GHGs}\left(\mathrm{kgCO}_{2} \mathrm{eq} \mathrm{fu}-{ }^{-1}\right)$ & $\mathrm{SO}_{2}\left(\mathrm{gSO}_{2} \mathrm{eq} \mathrm{fu}-1\right)$ & Water $\left(\mathrm{m}^{3} \mathrm{fu}^{-1}\right)$ & $\mathrm{EF}(\mathrm{gha})$ \\
\hline Base case & 0.332 & 1.675 & 0.240 & $6.51 \mathrm{E}-04$ \\
\hline Option 1 & 0.324 & 1.599 & 0.238 & $6.40 \mathrm{E}-04$ \\
\hline Option 2 & 0.326 & 1.621 & 0.240 & $6.51 \mathrm{E}-04$ \\
\hline Option 3 & 0.332 & 1.659 & 0.240 & $6.51 \mathrm{E}-04$ \\
\hline Option 4 & 0.331 & 1.651 & 0.240 & $6.51 \mathrm{E}-04$ \\
\hline
\end{tabular}


2. Cerutti AK., Bagliani M., Beccaro GL., Gioelli F., Balsari P., Bounous G. 2011. Evaluation of the sustainability of swine manure fertilization in orchard through ecological footprint analysis: results from a case study in Italy, J Clean Prod, 19, 318-324.

3. Cuadra M., Bjorklund J. 2007. Assessment of economic and ecological carrying capacity of agricultural crops in Nicaragua, Ecol Indic, 7, 133-149.

4. Dallinger J. 2011. Oil palm development in Thailand: economic, social and environmental consideration, Oil Palm Expansion in South East Asia: trends and implications for local communities and indigenous people. [http://www.forestpeoples.org/ sites/fpp/files/publication/2011/11/chapter-1-oilpalm-development-thailand-economic-social-andenvironmental-considerations.pdf]

5. De Camillis C., Raggi A., Petti L. 2010. Tourism LCA: state of the art and perspectives, Int J Life Cycle Ass, 15, 148-155.

6. DEDE. 2014. Department of Alternative Energy Development and Efficiency, Thailand Alternative Energy Situation 2014.

7. Diaz E., Fernandez J., Ordenez S., Canto N., Gonzalez A. 2012. Carbon and ecological footprints as tools for evaluating the environmental impact of coal mine ventilation air, Ecol Indic, 18, 126-130.

8. Ewing B., Reed A., Rizk S., Galli A., Wackernagel M., Kitzes J. 2008. Calculation methodology for the National Footprint Account 2008, Global Footprint Network, Oakland.

9. FAOSTAT2015, Food and Agriculture Organization of the United Nations, Statistic Division. 13th October, 2015.

10. Global Footprint Network. 2009. Ecological Footprint Standards 2009, Global Footprint Network, Oakland.

11. Global Footprint Network. 2010. Living Planet Report 2010. Global Footprint Network, London.

12. IGBP. 2013. Ocean Acidification Summary for policymakers, in Third Symposium on the Ocean in a High- $\mathrm{CO}_{2}$ world, International GeosphereBiosphere Programme: Stockholm, Sweden.

13. ISO 14040. 2006. ISO 14040:2006-Environmental management-Life cycle assessment-principles and framework, International Organization for standardization, Geneva.

14. Irrigation Water Management (IWM). 2011. The study on reference crop evapotanspiration by Penman-Montheith method of the Irrigation Water Management Division, Royal Irrigation Department, Bangkok, Thailand.

15. Kissinger M., Gottlieb D. 2012. From global to place oriented hectares-the case of Israel's wheat ecological footprint and its implications for sustainable resource supply, Ecol Indic, 16, 51-57.

16. Kitzes J., Galli A., Rizk S., Reed A., Wackernagel M.
2008. Guidebook to the National Footprint Account: 2008 Edition, Global Footprint Network, Oakland.

17. Lee YJ., Peng LP. 2014. Taiwan's ecological footprint (1994-2011), Sustainability, 6, 6170-6187.

18. Mekonnen MM., Hoekstra Y. 2011. The green, blue and grey water footprint of crops and derived crop products, Hydrol Earth Syst Sc, 15, 1577-1600.

19. National Corn Growers Association. 2013. World of Corn: Unlimited Possibilities.

20. Niccolucci V., Galli A., Kitzes J., Pulselli RM., Borsa S., Marchettini N. 2008. Ecological footprint analysis applied to the production of two Italian wines, Agr Ecosyst Environ, 128, 162-166.

21. Ohimain, EI., Izah, SC., Obieze, FAU. 2013. Material-mass balance of smallholder oil palm processing in the Niger Delta, Nigeria, Adv J Food Sci and Tech, 5(3), 289-294.

22. Rees W. 1992. Ecological footprints and appropriated carrying capacity: what urban economics leaves out, Environ Urban, 4, 121-130.

23. Roos E., Sundberg C., Hansson P. 2010. Uncertainties in the carbon footprint of food products: a case study on table potatoes, Int J Life Cycle Ass, $15,478-488$.

24. Scotti M., Bondavalli C., Bodini A. 2012. Ecological footprint as a tool for local sustainability: the municipality of Piacenza (Italy) as a case study, Environ Impact Asses, 29, 39-50.

25. Solis-Guzman J., Marrero M., Ramires de Arellano A. 2013. Methodology for determining the ecological footprint of the construction of residential buildings in Andalusia (Spain), Ecol Indic, $25,239-249$.

26. Thaiusa B. 2002. Silvicultural management of private eucalyptus plantations for wood chips in Thailand, Proceedings of the International Symposium Eucalyptus Plantations (Research, Management and Development) 1-6 September 2002.

27. Wachernagel M., Rees W. 1996. Our ecological footprint: reducing human impact on the earth, New Society, Gabriola Island, BC.

28. Wada Y. 1993. The appropriated carrying capacity of tomato production: the Ecological Footprint of hydroponic greenhouse versus mechanized open field operations. M.A. Thesis. School of Community and Regional Planning, University of British Columbia, Vancouver, Canada.

29. Yoshikawa N., Amano K., Shimada K. 2011. Ecological footprint evaluation of Japanese domestic food consumption considering water footprint, in ICM (the dahlem cube, Berlin) 28-31 August 2011.

30. Zamagni A., Buttol P., Porta PL., Buonamici R., Masoni P., Guiness J., Heijungs R., Ekavall T., Bersani R., Bienkowska A., Pretato U. 2008.Critical review of the current research needs and limitation related to ISO-LCA practice ENEA, Bologna, 106. 